\title{
The Influence of Muhammad Abduh in Indonesia
}

\author{
Ahmad Nabil Amir \\ International Institute of Islamic Thought and Civilization (ISTAC-IIUM), \\ Kuala Lumpur, Malaysia \\ Email: nabiller2002@gmail.com \\ Tasnim Abdul Rahman \\ Faculty of Islamic Contemporary Studies (FKI), Universiti Sultan Zainal \\ Abidin (UniSZA), Kuala Nerus Terengganu, Malaysia \\ Email: tasnimrahman@unisza.edu.my
}

\begin{abstract}
Muhammad Abduh had a remarkably profound and lasting impact in Indonesia. His reformist ideas had a strong repercussion in the political and social landscape of the region. They were readily adopted by major Islamic movements, notably Muhammadiyah, al-Irshad and Persatuan Islam (Persis). Abduh's Tafsir al-Manar deeply influenced some momentous works of Qur'anic exegesis, such as Tafsir al-Azhar, Tafsir alQur'an al-Karim, Tafsir al-Qur'an al-Madjid (Tafsir al-Nur), Tafsir alMisbah and Tafsir al-Furqan. His Majallat al-Manar, which was planned and collaborated with Rashid Rida since 1898, highly inspired reformoriented scholarship evident in journals such as al-Munir, and alDhakhirah al-Islamiyah. This study aims to analyze the influence of Abduh's modernism in Indonesia. It attempts to discover the implication of his principle and philosophical tradition in the religious reform and modern movement in Indonesia. The method of study is based on qualitative approaches, using content analysis method. It was conducted based on library method to investigate the related data from primary and secondary sources. The data was analyzed using descriptive-analytical approaches, by way of inference (istisqa') and deductive (istinbat) method. The paper concluded that Abduh had profound and extensive influence in the Archipelago, especially his impact on Islamic reform and renewal (islah and tajdid) in Indonesia.
\end{abstract}

Keywords: Muhammad Abduh, Indonesia, Islamic Reform 


\begin{abstract}
Abstrak
Muhammad Abduh memiliki pengaruh yang sangat besar dan abadi di Indonesia. Ide-ide reformisnya memiliki dampak yang kuat dalam lanskap politik dan sosial wilayah tersebut. Mereka dengan mudah diadopsi oleh gerakan-gerakan Islam besar, terutama Muhammadiyah, al-Irshad dan Persatuan Islam (Persis). Tafsir al-Manar Abduh sangat mempengaruhi beberapa karya tafsir al-Qur'an yang penting, seperti Tafsir al-Azhar, Tafsir alQur'an al-Karim, Tafsir al-Qur'an al-Madjid (Tafsir al-Nur), Tafsir al-Misbah dan Tafsir al-Furqan. Majallat al-Manar-nya, yang direncanakan dan dikolaborasikan dengan Rasyid Ridha sejak 1898, sangat mengilhami keilmuan berorientasi reformasi yang terbukti dalam jurnal-jurnal seperti al-Munir, dan al-Dhakhirah al-Islamiyah. Penelitian ini bertujuan untuk menganalisis pengaruh modernisme Abduh di Indonesia. Ia mencoba menemukan implikasi dari prinsip dan tradisi filosofisnya dalam reformasi agama dan gerakan modern di Indonesia. Metode penelitian didasarkan pada pendekatan kualitatif, dengan menggunakan metode analisis isi. Penelitian ini dilakukan berdasarkan metode kepustakaan untuk menyelidiki data terkait dari sumber primer dan sekunder. Analisis data menggunakan pendekatan deskriptif-analitis, dengan metode inferensi (istisqa') dan deduktif (istinbat). Makalah ini menyimpulkan bahwa Abduh memiliki pengaruh yang dalam dan luas di Nusantara, terutama dampaknya terhadap pembaruan dan pembaruan Islam (islah dan tajdid) di Indonesia.
\end{abstract}

Kata Kunci: Muhammad Abduh, Indonesia, Reformasi Islam

\title{
Introduction
}

The need for reform initiated by Muhammad Abduh in Egypt inevitably profound and instructive. The movement inaugurated by Abduh had lasting and phenomenal impact in Indonesia, celebrated by many great scholars and reformists branded as Kaum Muda (the Young Turks) who were deeply influenced by his ideas and inspirations. The basic construct of Abduh's modernism was intrinsically based on his philosophical tradition that espoused rational principle and the central position of 'aql (reason) and the inevitable need for ijtihad. His modern aspiration was deeply influenced from the revolutionary ideas of Jamal al-Din al-Afghani and his influential pan Islamic ideal that was largely propounded in the periodical al-Urwa al-Wuthqa that provide the theoretical ground for the struggle.

The theoretical foundation of this study is based on the theoretical postulate of Muhammad Asad that pointed out that Abduh had an intrinsic influence in almost every manifestation of modern Islam. This major influence was explicitly evidence in the underlying construct of contemporary Islamic thought that essentially projected 
back to the philosophical tradition of Abduh, as signified in his preface to his tafsir, The Message of the Qur'an:

The reader will find in my explanatory notes frequent references to views held by Muhammad 'Abduh (1849-1905). His importance in the context of the modern world of Islam - can never be sufficiently stressed. It may be stated without exaggeration that every single trend in contemporary Islamic thought can be traced back to the influence, direct or indirect, of this most outstanding of all modern Islamic thinkers. The Qur'an commentary planned and begun by him was interrupted by his death in 1905; it was continued (but unfortunately also left incomplete) by his pupil Rashid Rida under the title Tafsir al-Manar, and has been extensively use by me. (Muhammad Asad 1980)

By emphasizing this point, the study set forth to analyze Abduh's major influence in contemporary Islam in Indonesia. It has significance difference from previous studies on Abduh, that it attempted to elucidate this impact in-depth, by explicating his profound and broad influence in contemporary Islamic thought as reflected in various works of tafsir, journals, Islamic movement, institution and school of theology. Abduh's inspiring works continued to resonate among the young faction (Kaum Muda) or the modernist in Indonesia who continued to espoused and carried on his tradition. Notable among them are the influential ulama forthcoming from Minangkabau, North Sumatra, Betawi, Bandung and Central Java, among others. Abduh's indelible legacy in Indonesia is evident in the scholarship he inspired among reform-oriented scholars in the form of tafsir, journals, press, magazines, schools, religious movements and institutions that flourished in the 19th and 2oth century.

Muhammad Abduh's ideas began to spread in the 19th-2oth century through scholars trained at al-Azhar who brought back the spirit of Islamic reform (tajdid) into Indonesia. The strong connection established with the al-Manar's circle in Egypt helped to spread Abduh's progressive views. This was instrumental in sowing the seeds of the reformist movement in Indonesia. Through this connection, the foundation for religious reform was hailed at unprecedented scale, by great revivalist and activist, the torch bearer of reform, as stated by Mohd Shuhaimi Ishak (2007) in his dissertation on the impact of Abduh's rationality on Harun Nasution's worldview: 
The birth of the modernist reformist Pan-Islamism advocated by alAfghani and 'Abduh, attracted a vast audience among young students. Cairo, during the colonial times and particularly in the 1920s, provided a fertile ground for the Southeast Asian students.

The increasing influence and network established between the Middle East and the Malay-Indonesian Archipelago firmly established Abduh's lasting influence in the region, as acknowledged by Azyumardi Azra (2006) in his study of the transmission of Abduh's reformism in the region:

The increasing contact between Muslims from the Middle East and the Malay Archipelago was due to many factors, including the rapid development in navigation technologies, the opening of the Suez Canal in 1869, the monetization of the colonial economy, which benefitted certain classes in the colony and the greater global community of populations.

Many factors contributed to establish the contacts between MalayIndonesian world and the Middle East, mainly the learning activity in Cairo and the invention of printing machines (Hafiz Zakariya 2007). Haramayn was the largest gathering point of Muslims from all over the world, where ulama, Sufis, rulers, philosophers, poets and historians met and exchanged information (John Voll 1982). Cairo was the cornerstone of tradition and the epicenter of cultural and religious movements. This historical significance was tacitly alluded by Zakaria Mohieddin, former Prime Minister of Egypt: Cairo has been and will always be a citadel of faith and a centre of Islamic activity for the general welfare of the people (Naseer, H. Aruni 1977).

Al-Manar's significant connection with Malay-Indonesian world through the influential network of Egyptian alumnus and reformists was instrumental in unleashing a new tide of reform and strong rationalistic and scientific discursive that deeply inspiring their theological and philosophical outlook, as asserted by Michael Laffan (2004): With the expansion of the resident community of Indonesians in Egypt, the Cairene body has now come to represent far more than the revivalist scripturalism laid out by Muhammad Abduh. It has developed significant impact and inspired dynamic connection with the Malay-Indonesian world and through this relationship, ideas on Islamic reformation that were advocated by Egyptian reformists were 
absorbed and diffused amongst the Muslim society in this region (Hamid, I. 1985).

In early 2oth century, the continued consciousness of modern ideal was exacerbated with the penetration and wide circulation of islah-oriented journals, magazines and newspapers such as al-Munir (West Sumatera), al-Huda, al-Iqbal (Java), al-Mir'ah alMuhammadiyah (Yogyakarta), al-Tadhkirah al-Islamiyah, Pembela Islam (Bandung), al-Irsyad (Pekalongan), and other influential works in Indonesia contributed to extend Abduh's influence and sparked an unprecedented intellectual movement for reform in Indonesia.

Abduh's modern aspiration and philosophical tradition and principle attracted many scholars from various persuasion and school of thoughts. This was reflected in the request that was directed to alManar "which emanates from three groups: Southeast Asian students in the Middle East, Arabs living in the Southeast Asia and indigenous Southeast Asian readers of al-Manar" and primarily related to themes on Islam and modernity, religious practices and aspirations for religious reform (Jajat Burhanuddin 2005). The principal question came in 1930 from Shaykh Muhammad Basyuni b. 'Imran (1885-1981) from Sambas, West Kalimantan, and was addressed to Shakib Arslan (1869-1946). He had two important queries; he asked why Muslims (particularly in the Malay world) decline and why non-Muslims advance. The response by Arslan was published in a series of articles in al-Manar and later compiled in a work entitled Li madha ta'akhkhar al-Muslimun wa limadha taqaddama ghayruhum? [Why are Muslims in decline while others progress?] Juta Bluhm in her essays has thoroughly investigated the correspondence and dialogue, looking into the contact initiated between Cairo and the Malay-Indonesian world, pointing out that:

There was interaction between al-Manar readers in the Malay world and the editors of the periodicals. In this regard, Malay individuals from Malaya, Kalimantan, Sumatra and other parts of the region wrote to those editors seeking advice and offering opinions on a broad range of theological questions, economic and environmental problems, technological advances, issues of current political concern such as patriotism and a range of other matters...indeed, during the period of its publication (1898-1936), alManar published 26 articles and some 135 requests for legal opinions from the Malay-speaking world. (John Bluhm 1983) 
In this way it arguably challenged the traditional orthodoxy and reopening a more inclusive views and rationalistic outlook and has momentous significant in defining and inspiring change in Islam's modern history and empowering its process.

The objective of this study is to highlight the profound influence of Abduh's modernism in Indonesia. It attempts to investigate the implication of his aspiration and philosophical tradition in the religious reform and modern movement in Indonesia. For this purpose, it surveys various works of tafsir, press, institution, religious movement, and school of theology that resonated Abduh's influence and espoused his principle ideas and doctrine.

The method of study is based on qualitative approaches, using content analysis method. It was conducted based on library method to investigate the related data from primary and secondary sources. The data was analyzed using descriptive-analytical approaches, by way of inference (istisqa') and deductive (istinbat) method to reach and establish the finding and conclusion.

\section{Results and Discussion}

\section{Abduh's Impact on Tafsir Literature}

Tafsir al-Manar, dictated by Muhammad Abduh and later published by Muhammad Rashid Rida in his periodical al-Manar, was highly influential in the Malay Archipelago and had extensive impact on the literature of tafsir produced in the 2oth century. It essentially promoted deeply scientific enquiry and rational outlook, showcasing a significant methodology of Qur'anic exegesis that celebrated the power of reason, encouraging critical spirit and definitive ijtihad (independent reasoning). The volume featured commentary based on systematic exposition of rational principle and modern scientific framework, betraying high level of ijtihad and a radical departure from the conventional ways of religious orthodoxy of classical tafsir. Echoing the principles of Abduh, Muhammad Asad (1980) stressed this point in his magnum opus The Message of the Qur'an:

The spirit of the Qur'an could not be correctly understood if we read it merely in the light of later ideological developments, losing sight 
of its original purport and meaning. In actual fact we are bent to become intellectual prisoners of others who were themselves prisoners of the past and had little to contribute to the resurgence of Islam in the modern world.

The Tafsir also referred to many classical and medieval works of exegesis, ranging from al-Tabari to al-Alusi as its primary sources, while employing independent and sound reason in interpreting the text and elucidating the ideological and theological questions pertaining to the ayah. It was hailed as among the greatest work of tafsir in the 2oth century. Indeed, it has ushered a modern scientific approach of exegesis in the continent, while becoming the primary reference of tafsir in the Malay-Indonesian Archipelago. The discussion extended into theological and socio-ethical reasoning, addressing the intrinsic meaning and contextual application of the ayah and its relevancy to modern context of Islam and its social interest. In his analysis of the key influence of Egyptian reformists on the works of tafsir manuscript in the Malay Archipelago, M Abdullah (2012) remarked:

The trend of writing tafsir (exegesis) manuscripts in the Malay Archipelago during the first of the 2oth century was very influenced by the Islamic reformation in Egypt initiated by Syaykh Muhammad 'Abduh (1849-1905), which was later expanded by his disciples such as Sayyid Muhammad Rasyid Rida (1865-1935), Syaykh Mustafa al-Maraghi (1881-1945) and other scholars with similar orientation.

In this particular part we shall survey the influence of Tafsir alManar on popular tafsir literature in Indonesia, especially produced in the zoth century that manifested the intrinsic philosophy and rational tradition of Abduh such as Tafsir al-Azhar, Tafsir al-Quran al-Karim, Tafsir al-Quranul Madjied (Tafsir an-Nur), and Tafsir al-Furqan.

Tafsir al-Azhar was arguably one of the leading modernist works of tafsir in modern times. Penned by Shaykh Haji Abdul Malik bin Abdul Karim Amrullah (Hamka), it critically played a crucial role in realizing 
the aspiration of reform and renewal in Indonesia. The tafsir initially was compiled from Hamka's lecture on Qur'anic commentary delivered at al-Azhar Mosque, Kebayoran Baru, Jakarta after subuh (seasonal class after dawn). Since 1959, the commentary was gazetted in Gema Islam, an influential periodical which release his works that profoundly reflected the idealism of Muhammad Abduh, the leading exponent of modern Islam in Egypt (Hamka 1967), as indicated in the style and approach of the tafsir. The largest part of the tafsir from sura al-Mu'minun (the Believers) to al-Baqara (the Heifer) was accomplished in his cell while languishing in solitary confinement (27 Jan 1964-21 Jan 1967) when Hamka was falsely charged and accused of plotting to topple the democratic government. Dedicated to young Muslims with an inadequate knowledge of Arabic who were trying hard to understand the Qur'an, the Tafsir served as da'wah materials for leading mubaligh (Islamic proselytiser) and cadre of Muhammadiyah.

The basic ideas formulated in the Tafsir seems to encapsulate the entire worldview projecting the his essential outlook and ideas on religious reform, designed in such a way as to present a discursive and an interpretative argument of subjects of divine law, jurisprudence, mysticism, faith, philosophy, science, nature, spiritual and ethical teaching of the Qur'an. The defining pattern of tafsir rigorously crafted based on al-adabi al-ijtima'i (socio-artistic) approach employing certain descriptive, historical and analytical method. Throughout the work, it betrayed certain exceptional form of socio-artistic consideration, emphasizing on social dimension and rational understanding of the text. Much of the commentary was essentially based on Tafsir al-Manar that inspired his rational and dynamic ways of analysing the text. It portrayed systematic treatment of the scripture manifesting in-depth hermeneutical and philosophical premise and arguments. The Tafsir seeks to elaborate Abduh's significance reasoning, and his metaphysical penetration, implying in the text, and informed by his progressive outlook: 
A very captivating and appealing commentary to be an example to the interpreter, is Tafsir al-Manar, penned by Sayyid Rashid Redha, based on the teachings committed by his teacher Imam Muhammad Abduh. His Tafsir, apart from specifically describing knowledge concerning religion, hadith, fiqh and history, also adopting the verses to contemporary development of politics and society, which is appropriate to the time when the tafsir was composed. (Hamka 1982)

Released in 1961, the Tafsir clearly portrayed the impact of Abduh's reformism in its exposition, as remarked by Milhan Yusuf (1995, i) in his thesis probing on Hamka's method in interpreting and contextualizing legal text of the Qur'an in Tafsir al-Azhar: Having been influenced by the Muslim reformist ideas championed by Muhammad Abduh and his colleagues, Hamka attempted to disseminate and ameliorate the reform ideas in his country, Indonesia, through the means available to him, that is by preaching and writing. Milhan also described the principal influence of Abduh's rational stance and his critical theology of jurisprudence that impacted the Tafsir: Hamka's conception of the law portrays his challenge and struggle towards the abolishment of taqlid (uncritical acceptance of the decisions made by Muslim predecessors) and the implementation of ijtihad (personal opinion). (Milhan Yusuf 1995)

Hamka had been exposed to the reform tradition brought from the Middle East since early years in his time at Minangkabau, as evidenced in his keynote address on the occasion of receiving a honorary doctorate from al-Azhar University: I admit that I never learned, either in al-Azhar or at Cairo University, but my intimate relationship with Egypt had long been embedded, since I managed to read Arabic books, especially of Shaykh Muhammad Abduh and Sayyid Rashid Rida (Hamka 1958, 24). Muhammad Abduh's influential tafsir and his philosophical tradition has been the principle groundwork that enlightened the rational interpretation of Tafsir AlAzhar. Expressing this profound inspiration from Abduh's authoritative and phenomenal work, i.e., Tafsir al-Qur'an al-Hakim li al-Ustadh Muhammad 'Abduh, Hamka wrote: Despite that he (Rida) 
wrote only 12 juz' (chapters), the compilation still useful to guide in continuing this interpretation of al-Azhar till the end...the strategic approach he uphold is still fresh and can be emulated, not stale or exhausted. (Hamka 1982)

The approach of Tafsir al-Azhar was primarily based on critical interpretation espoused by Muhammad Abduh in Tafsir al-Manar which advocated the supremacy of reason and upheld the necessity of ijtihad based on the principle of maslahah (general welfare). In this regard, Abduh explicitly asserting a claim to renewed interpretation (ijtihad) of Islamic law based on the requirements of social justice (maslahah) of his own era. According to Abduh, where there seems to be a contradiction between texts (nas) and social justice (maslahah), then social justice must be given precedence. Abduh supports the principle based on the notion that Islamic law was revealed to serve, inter alia, human welfare. Hence, all matters which preserve the wellbeing of the society are in-line with the objectives of the sharia and, therefore, should be pursued and legally recognized. Abduh believed that independent thinking (ijtihad) would enlarge the scope of knowledge because most of the aspects of human welfare (mu'amalat) can be further elaborated with the use of reason ('aql).

In his effort to relates the teachings of the Qur'an with the religious spheres and bringing structural reform of life, the commentary seeks to connect it with moral and ethical values and social consciousness. The formulation of tafsir al-adabi al-ijtima'i (socio-cultural) conclusively shows resolute struggle in envisioning and bringing new consciousness of Islamic life and developing credible moral spiritual principle. Struggling to uphold the ideal of reform (islah), Hamka aspired to bring forth underlying spirit and reinvigorate its spiritual and ethical consciousness. The extensive influences of Abduh's progressive views, was reflected in Hamka's commentary on the need to contextualized the social welfare in legal rulings:

In modern times, nowadays, Syeikh Muhammad Abduh once asked the opinion on laborers who work hard day and night in mining by taking 
turn, they can pay fidyah (compensation), not qada' (replacement). Since, some of them going to work at night, only come out tomorrow at noon. And, some a daylong, only come out at night. Some, a nightlong, only returned home at the morning. Probably, included also here ship workers, sailors, and the like. Those seafarers not only travellers anymore, even their livelihoods are on the ship from young to old age until retirement. If only after retirement, you were asked to make a qada' (replacement), how much must be replaced. Only if there is time for them to have leave which coincides with the month of Ramadan, they will fast for a full month at home. (Hamka 2017)

The ideology of reform upheld developed an influential impact in modern times, betraying the deep intellectual and insightful realization of religious ideal and principle. Summarizing the reformative context and philosophical tradition espoused by Abduh, Hamka emphasizes its rational spirit that fundamentally challenge the status quo, superstitious belief and taqlid, aspiring to initiate constructive idea of reform and to rediscover authentic religious spirit and independent thought in the quest of truth. A fact reiterated by Wan Sabri Wan Yusof (1997) in his thesis: Hamka, who was a reformer, also interpreted verses of the Qur'an in the context of his reform ideas in which bid'ah and superstition were the main targets.

This clearly resonates Abduh's aspiration and struggle to advocate reform, by outlining an approach to return to a pure understanding of Islam by interpreting the Qur'an and the Sunna through the use of independent and rational investigation (ijtihad) from the allegedly blind reliance (taqlid) upon the opinions of the medieval jurists. The phenomenal impact of the Tafsir was unprecedented, which had developed immense spiritual and moral consciousness and understanding of deep-layered meaning and essence of the Qur'an. It set forth significance socio-ethical and contextual method in dealing with the text, by emphasizing the central role of 'aql (reason) and local-cultural experience that coloured his approaches and passion for scientific and rational arguments, aspiring to bring momentous change in society: 
A visible concern in his Tafsir was the issue of 'aql (mind), rationality and reason. This concern is definitely related to his support of the reformist movement and the neglect of Muslims over the use of reason and their independence over taqlid. (Rosnani Hashim 2010)

Tafsir al-Qur'an al-Karim is a monumental work of Quranic exegesis that fundamentally derived its interpretation and commentary from Tafsir al-Manar. The work was essentially founded upon Tafsir al-Manar; Tafsir al-Jawahir and Tafsir al-Maraghi in term of its approaches and ideas. It was the fruit of painstaking efforts of Abdul Halim Hassan (1901-1969) and his colleagues and disciples Zainal Arifin Abbas (1912-1977) and Abdur Rahim Haitami (1910-1948), a remarkable attempt to produce a highly scientific and modern exegesis that profoundly extended al-Manar contextual and scientific approach and rational spirit of tafsir. It was crafted according to the manhaj al-adabi ijtima'i (socio-cultural method) that reflected the socio-political setting of the time. The commentary employed a hermeneutic and inter-textual approach that reflected the understanding of powerful social dynamic and modernist discourse and extensive principle of contextual and rational framework brought forth in al-Manar.

Tafsir al-Qur'an al-Madjied famously known as Tafsir an-Nur is a scientific work of Qur'anic exegesis that set forth to bring contemporary discussion of the Quran, its historical and modern significance in the context of comprehensive intellectual history of Islam. Penned by Teungku Mohammad Hasbi ash-Shieddiqy (19041975), it explicated the ideas of reform advocated by Muhammad Abduh and Rashid Rida in Tafsir al-Manar. The work addresses spiritual and theological problems concerning the text and the dynamic of religious renewal as advocated in the Qur'an. It also addresses themes related to classical debates of Qur'anic commentary in its historical context especially of medieval tafsir. Its concern was to projecting an intellectual outlook of Islamic ideal and to advocate Abduh's major aspiration for reform (islah) and renewal (tajdid). It derived its various arguments from Abduh's principle works especially 
Tafsir al-Manar, Tafsir Juz 'Amma, Risalat al-Tauhid and al-'Urwa alWuthqa (the firmest bond). Ash-Shieddieqy also published a brief commentary Tafsir al-Bayan which is largely based on Tafsir alMaraghi and Tafsir al-Manar and were instrumental in realizing social, political and religious reform in Indonesia.

Kitab al-Furqan fi Tafsir al-Qur'an or al-Furqan Tafsir al-Qur'an is an acclaimed work by A. Hassan or rather Hassan bin Ahmad. It took him about 30 years to accomplish the work, extending from the period of 1920-1950, where it was published in four consecutive editions, in 1928 (first impression), 1941 (Persatuan Islam), 1953 and 1956. A major commentary by the leading activist of Persatuan Islam, it undertakes to addresses his principle stance in the context of religious reform and the process of modernity, and strongly advocated the ideas of reform inspired by Muhammad Abduh in Tafsir al-Manar. A. Hassan wrote this lengthy tafsir based on his puritanist leaning using literal approach (harfiyah), that is, word by word translation, except for words that could not be translated in such a way in the harfiyah sense, in which case he resorted to their ma'nawiyah (figurative) meaning. The work adopted essentially scientific method and emphasized the critical and rational dimension of tafsir, reflecting the foundational framework of modern commentary inspired by Abduh and Rashid Rida in Tafsir al-Manar.

Other influential commentary in the late 19th and early 2oth century that were influenced by Tafsir al-Manar includes Tafsir alBurhan by Haji Abdul Karim Amrullah (Haji Rasul) and Tafsir alMisbah by Prof. Dr. H.M. Quraish Shihab. Tafsir al-Misbah is a 30volume work by Quraish Shihab that was principally designed according to the intellectual framework of Tafsir al-Manar. Shihab had critically analysed Tafsir al-Manar in his two important works Rasionalitas Al-Qur'an: Studi Kritis Tafsir al-Manar (Qur'anic Rationality: Critical Study of Tafsir al-Manar) and Tafsir al-Manar: Keistimewaan dan Kelemahannya (Tafsir al-Manar: Its Excellency and Deficiency) treating various aspects of historical critics and praise brought forth to the Tafsir. He also analysed Abduh's principle 
framework and approaches of tafsir in his foreword to the translation of Kitab Juz 'Amma of Muhammad Abduh by Muhammad Bagir (1999). He rigorously uphold the principle of "al-muhafazah 'ala alQadim al-salih wa akhdhu bi al-jadid al-aslah" (keeping or maintaining the old tradition that is good and taking the new notion that is better) that have become the methodological anecdote and reminiscence culture in the Pesantren (traditional religious boarding school).

\section{On Press and Journal}

The celebrated journal, al-Manar, edited and published by Muhammad Rashid Rida between 1898-1935, had great ramifications and lasting influence in Indonesia. The journal remained in publication for almost 37 years in the first half of the twentieth century that marked the beginning of unprecedented reform in the Muslim world led by Rida. It addresses Islam's momentous challenge and the common struggle to liberate its people, and bring forth significance vision for intellectual renewal and liberation, as alluded by Albert Hourani (1962):

Islamic journalism experienced its first zenith in Egypt with the publication of Rida's journal, as the early leading salafi scholar in the Muslim world. From the time of its foundation, al-Manar became Rida's life and in it he published his reflections on the spiritual life, explanation of Islamic doctrine, endless polemics, commentary on the Qur'an, fatwas, his thoughts on world politics, etc.

In his illustrious work al-Tafsir wa Rijaluhu (Qur'an and its exegetes), Muhammad al-Fadil b. 'Ashur $(1966,196)$ narrated the fame of al-Manar, Rida's most momentous and canonical work and the incredible reputation it accorded to Abduh:

With the beginning of al-Manar's publication in the year 1315/1898 al-Ustadh al-Imam's thoughts started to gain prominence and with the expansion of al-Manar those thoughts began to growing and 
spreading widely, to the extent that Shaykh Muhammad Abduh's leadership was institutionalized thanks to the publication of alManar. In it his articles, reports, fatwas were made known and his attitudes in defending Islam. In it he answered also to his opponents and enemies. In it his name was praised and given the title al-Ustadh al-Imam. In it, the most important consideration of all, al-Manar Qur'an commentary was published. (Assad Nimer 1976)

Al-Manar espoused the modernist vision of Islam and developed liberal and progressive views of Islam, especially its religious doctrine, philosophy, and ethical teaching. It also probe into the underlying crisis of the ummah's political and social unrest and the way to advancing its civilization (al-umran). The work essentially hailed as the principle reference of modern salafis and its projected ideology in modern times. Al-Manar carried the pan-Islamic ideal of Jamal al-Din al-Afghani (1838-1897) and Muhammad Abduh expounded in the periodicals al-'Urwa al-Wuthqa, aims to salvage the ummah from its current malaise, denouncing political tyranny and ignite a revolution against the British colony. Al-'Urwa al-Wuthqa was suppressed by the British, published shortly between March to October 1884, gaining access to Muslim lands through its advocacy of Pan-Islamic ideals (alittihad al-Islam or Islamic unity), by cajoling the masses to revolt against their masters, motivating the critical use of reason and the reopening of philosophical inquiry to help the condition of Muslims at the time (Rida 1931). The philosophy and underlying objectives of al'Urwa al-Wuthqa were the guidance of man to supremacy on earth as deputy of God for the establishment of love and justice (Raden Hajid 1954). This aspiration was illustrated by 'Afaf Lutfi al-Sayyid (1968) in his historical analysis of European colonies and the condition of modern Egypt:

A Pan-Islamic paper that aimed its message to all the Muslims of the world and urged them to unite and restore the lost glories of Islam, al'Urwa was specifically aimed at freeing Egypt from the British occupation. This was to be effected by stirring up public opinion in 
Egypt and also in India. The ideas expounded in al-'Urwa may be summarized into two main themes. The first is that true Islam has become corrupted through ignorance and must therefore be reformedotherwise the Muslims all faced extinction; the second point is that the Muslim countries had been betrayed by their rulers, who, swayed by personal motives of greed and aggrandizement, gave foreigners a free hand in their countries. The consequence was that the Europeans who coveted Muslim lands took advantage of the inner discords of Islam and sought to destroy the religious unity of the Muslim nations. ('Afaf Lutfi al-Sayyid 1968)

The dissemination of Abduh's reformism erupted a new consciousness to restore civilizational and religious dynamism and to rediscover ummatic pan Islamism, revive and enlighten its spirit, and reclaim their past glory and leading role at global stage. This was realized with the rise of dynamic Islamic movements such as Muhammadiyah, al-Irshad, Serikat Islam, Jong Islamieten Bond (JIB or Young Muslim Union) and Persatuan Islam, and through the publication of islah-oriented press and journals such as al-Munir that attempted to bring forth substantive reform and progressive vision of Islam. The ensuing Pan-Islamic ideals revived Abduh's liberal aspiration and rational theology. In projecting this vision, al-Manar played a crucial role in inaugurating modern religious movement and rallying support from the masses, where:

Since al-Manar's existence at the end of the nineteenth century, that school of thought has made a vital contribution that in taking a different direction from the traditional exegesis in its methodology of explicating the Qur'anic verses. Being very concerned about religious, political and social reform, it has made a great impact in changing the worldview of Muslims in general. (Nadzirah Mohd 2006).

The main ideal advocated in al-Manar is tajdid and islah (renewal and reform) and its impact reverberated throughout the continent, sparking a vibrant and lasting rigorous tradition of reform in 
Indonesia. It inspired the publication of unprecedented islah-oriented magazines and journals such as Majallat al-Munir (1911-1916). This helped promote modern and progressive ideas through a balanced and rational interpretation of Islam.

Al-Manar was widely circulated in Sumatra, Java, Kalimantan and Sulawesi, with working agents in jakarta, Tjiandur, Surabaya, Semarang, Pontianak, Sambas and Makasar. The journal played a crucial role as cultural brokers, translating the new purity, rationalism and vitality of Islam into the Malay language - the Archipelago's lingua franca - and also into terms relevant to a local, MalayIndonesian frame of reference. (Henry Benda 1970)

Al-Munir (Radiating) was published in Padang Panjang, West Sumatra in 1911 by Haji Abdullah Ahmad, Haji Muhammad Thayeb and Dr Haji Abdul Karim Amrullah (Haji Rasul). Al-Munir espoused the modern idealism of Abduh and strived "to lead and bring Muslim umma to progress based on Islamic injunctions, to nurture peace among nations and human beings and to enlighten the Muslim umma with knowledge and wisdom" (Deliar Noer 1973). It was released fortnightly and each issue consisted of about sixteen pages printed in Jawi script. Al-Munir was spread rapidly in the whole Sumatra, Java, Sulawesi, Kalimantan and Malaya (Hamka 1967). The task of al-Munir was to inject dynamism, mobilize reform and instigate a rigorous islah movement. It functioned as the "candle" that illuminated the Muslim ummah in the Dutch East Indies (Azyumardi Azra 2006) who were severely suppressed and subjugated in their own mother land. In articulating the role of Islamic periodicals, al-Munir emphasized that it functioned "like a teacher who gives to its readers guidance in the right path, reminds them of their wrongdoings in the past, consoles those in grief, helps those in suffering from misery, awakens them to virtues and sharpens their reason (Azyumardi Azra 2006). This position, as illustrated by Syamsuri Ali (1997), was reminiscent of alImam and is a further indication that al-Munir was eager to continue al-Imam's mission. This fact is pointed out by Charles C. Adams (1968) in his classic study of Abduh's modernism arguing that if one takes 
into account its intellectual genealogy, it was only natural that alMunir should take over the role of al-Imam in spreading Kaum Muda teachings and opposing all enemies of Islam.

From its first edition, al-Munir proclaimed itself as a journal of Islamic religion, knowledge and information (Majalah Islam, Pengetahuan dan Perkhabaran). The publication openly discussed issues considered taboo by the traditionalist (Old Guard) - Kaum Tua, such as wearing of neckties, hats and taking photographs, which it argued never been forbidden in the Qur'an and hadith. It also insisted that Friday khutba (sermon before Juma'ah prayer) could be delivered in a language that was understood by the congregation; that Muslims should not follow blindly the classical legal school and juristic opinions (madhhab), and that the Shafiite school of law was not the only valid interpretation of Islamic precept and legal postulate.

Al-Munir also accorded special consideration and importance to Islamic organizations as a means for channelling the spirit of reform, encouraging enterprise, vigour, enhancing the nobility of science (kemuliaan ilmu), and cultivating brotherhood of mankind and nations (Azyumardi Azra 2006). Its struggle for reform met with a formidable challenge form its rivals and dissenters; its position was defied and confronted by conservative ulama and some unidentified troublemakers (tukang kacau) who launched the attack, on the grounds that preaching by means of journal was a western innovation and adopting the western way was bid'a (Azyumardi Azra 2006, 62). The journal was discontinued in 1916 after its printing house was burned down.

\section{On Islamic Movement and Institution}

The impact of Muhammad Abduh is manifestly evident in current religious movements and institutions in Indonesia, notable among them are Muhammadiyah, al-Irsyad, Pensyarikatan Ulama, Hizbul Muslimin, Pertubuhan al-Islah, Persatuan Islam, Sarekat Islam and Sumatera Thawalib. These institutions consisted of largely Muslim leaders and activist and modern advocate of Islam that constructively 
developed and extended Abduh's decisive tradition of reform, challenging the backward and decadent state of conservative 'old guards', and demand rigorous change of Muslim society toward progressive religious orientation and worldview. This momentous struggle was perceptively described by Mohd Kamal Hassan in his foreword to a riveting article compiled by Rosnani Hashim (2010) in Reclaiming the Conversation: Islamic Intellectual in the Malay Archipelago, investigating the intellectual legacy of eleven key thinkers in the Malay-Indonesian world:

It was truly the modernization of the Malay world in the context of the movement from myths and superstition to rational thinking (these scholars) lay the foundation of an integrated education system. Their creative-synthesis broke new ground, although they sometimes had to face the opposition from within their own communities and were labelled as the Young Turks (Kaum Muda), in contrast to the Old Guards (Kaum Tua), who were more conservative in the sense that they were not willing to examine their own traditions and consider the possibility of new ideas and approaches from other traditions and civilizations. (Rosnani Hashim 2010)

Persyarikatan Muhammadiyah is a significant religious movement, historically established as reformist Muslim organization founded by Kiyai Haji Ahmad Dahlan (d. 1923) on 18th November 1912 in Yogyakarta after the example of reformist movements in Egypt and India (Federspiel 2009). Highly reputed as the largest non-political Muslim organization in Indonesia, it was projected to reinforce and renew the profound ideal of Muhammad Abduh. Its phenomenal and unprecedented effort can be seen in the building of modern and progressive Islamic schools and institutions as well as in the mobilization of comprehensive social service and outreaching support, as alluded by George McTurnan Kahin (1952) in his description of their broad activism: 
The Muhammadiyah, an organization founded in 1912 at Yogyakarta by Kiyai Haji Ahmad Dahlan, a believer in modernist Islamic ideas. Originally devoted largely to education, the organization broadened its activities to include a wide range of social services: free clinics, poor relief, orphanages, publishing of the Koran in Javanese and Malay, libraries, etc., as well as Muslim schools. It conceived itself essentially as a propagator of Muslim culture and the non-political ideas of the modernist movement.

Muhammadiyah was founded to accomplish four crucial tasks: the purification of Indonesian Islam from corrupting influences and practices; the reformation of Muslim education; the reformulation of Islamic doctrine in the light of modern thought; and, the defence of Islam against external influences and attacks (Gibb, 1947).

Combined with his concern to address current malaise, Kiyai Dahlan has brought about significant reform in espousing social, cultural and spiritual development; playing dynamic role in the religious and political terrain of Indonesia, creating momentous legacy and intellectual tradition that continued to reverberate throughout the continent. His modernist ideas and progressive spirit was deeply remarked by President Sukarno in his eulogy to Kiyai: We know Kiyai Haji Ahmad Dahlan, not only as a founder and father of Muhammadiyah, but as precursor of freedom and Islamic reformism in Indonesia (Solichin 1960).

Dahlan's uncompromising principle in reasserting the progressive ideal of Islam and defending the reformed practices of shariah and religion was scrupulously portrayed by Solichin Salam (1960) in his inspiring work on K.H. Dahlan as the great champion and illustrious reformer of Islam: He was vehemently opposed to everything pertaining to conservatism, formalism and traditionalism in superstitious customs, as found in Muslim life in the early twentieth century. He explicitly embraced the momentous ideal of reform and strived to improve the poor condition of Muslim people by restoring their dynamism and past glory and achievement in medieval scientific ages: We must not reject the existence of change in nature. This 
change is a change of progress. Progress aims for the well-being of the world (Solichin 1963). He had inaugurated the dynamic modernist movement of Muhammadiyah that propelled the growth of creative culture and imprinted its lasting legacy in contemporary world: I must work hard to lay the cornerstone of this tremendous undertaking...and if I work hard to accomplish this project, which is almost finish, it will be easy for the people who come after me to accomplish the work (Solichin 1963). Muhammadiyah had a significant impact on modern life of Java. Dahlan was promulgated by his disciples and followers as the Mujaddid (Muslim reformer) whose teaching had historically defining the destiny of Islam, and who uncompromisingly strived to restore faith and life to the Muslims in Indonesia, freeing their minds from the shackles of blind obedience and cleansing Islam in Indonesia from the mud of indigenous and Hinduistic rituals (Hamka 1952). Muhammady Idris (1975), in his thesis analyzing the life and work of K.H. Ahmad Dahlan, summarized the achievement of Muhammadiyah and the popularity of its modernistic vision and its historical narrative of progressive tradition:

Through the Muhammadiyah, Kiyai Haji Ahmad Dahlan successfully spread his idea to the Muslim society in Yogyakarta. It became a popular means for Islamic reformers throughout Indonesia to launch ideas of modernization into the thoughts and customs of the Muslims. (Muhammady Idris 1975)

Al-Irsyad al-Islamiyyah or else Jamiyat al-Islah wal Irsyad al'Arabiyyah (Arab organization for reform and guidance), and later renamed as Jamiiyat al-Islah wal Irsyad al-Islamiyyah (Islamic organization for reform and guidance) was founded by Shaykh Ahmad Surkati al-Ansari (1876-1943) in 1913. It inspired a new social, religious and reform initiative to spread the modernist ideas promulgated in al-Manar. Surkati was the leading exponent of Abduh's modern aspiration, and has closely followed and subscribed to al-Manar publication from Egypt since its first edition. He initiated al-Irshad as modernist platform geared to accelerate the propagation of the ideology of islah (reform) and tajdid (renewal) in the region 
(Bluhm-Warn Jutta 1983). It was an influential movement active among Indonesia's Hadhrami community (Farish A. Noor, et al. 2008). Their momentous and significant trajectory of enlightened Islam has significantly attracted fundamental support from the masses, especially of Arab origin community in espousing the modernist cause, as stressed by Muhammadv Idris (1975): As one of the Arab-born pioneers of the movement, Shaykh Ahmad Surkati spread modernist orthodoxy in Indonesia, especially among the local Arab community. In 1911, Surkati was appointed as a teacher at Jam iyat al-Khayr (The Benevolent Society) in Jakarta. Here, he began to attract wide following and attained unprecedented fame as the leading reformer and precursor of Islamic modernism. He started recruiting teachers from Sudan, who share the same orientation for reform, among its pioneers were Ahmad al-'Aqib, Muhammad Nur b. Muhammad Khayr al-Ansari (Abu al-Anwar), Satti Muhammad Surkitti (Abu al-Fadl, Surkati's brother) and Hasan Hamid al-Ansari. These new recruits helped to consolidate reform in Jam iyat al-Khayr, where the appointees were well versed in Abduh's reformist ideas....who had studied at al-Azhar and regarded themselves as Abduh's devout followers and propagators of his reformist project (Deliar Noer 1973). Jam'iyat al-Khayr was a significance organization, that inspired noteworthy struggle and the rise of Hadhrami elite, the powerful clan of Arab origin. This was significantly depicted by Natalie N. Mobin-Kesheh (1996) in her note on the development of Arab periodicals of the Netherlands East Indies, in the period of 1914-1942, and the wide spread of modernist notion:

The nahdah al-hadramiyyah or 'hadrami awakening' can be dated from the establishment of the first Arab educational organization, Jamiyyah Khayr, in 1901. As it gained momentum in the ensuing decades, it was characterized by the proliferation of three novel social institutions: the young organization (jamiyyah), the modern style school (madrasa) and the newspaper (jaridah). 
In 1913, Surkati broke away from Jamiat Khair (Jamiyyah al-Khayr) that was considered as more conservative Arab educational association, and established instead Al-Irsyad Madrasa in Jakarta that gained wider influence among the hadramis as it taught a curriculum of religious and general subjects exclusively in Arabic, for which it employ [sic] teachers from the Arab Middle East (Farish 2008). It advocated fundamental reform and espoused Abduh's modern idealism, given its rational and modern perspective. The historical context and analysis of such madrasa was given by Farish Noor (2008) in his edited volume The Madrasa in Asia: Political Activism and Transnational Linkages:

The school was oriented towards Egyptian reformism; instead of classical fiqh texts it placed emphasis of the Qur'an and hadith; usul al-fiqh and the works of Abduh and other modern authors...many graduates of this madrasa spread the reformist message as teachers and preachers beyond hadrami circles in Indonesia.

Surkati major undertaking was to espouse and explicate the fundamental ideas and works of Abduh (especially his substantive commentary of Tafsir al-Manar) and advocated reform and Islamic modernism to the hadrami populace, where this book al-Tafsir Muhammad Abduh, contained precisely the teachings which Shaykh Ahmad Surkati himself was eager to spread among the Arab community (Muhammady Idris 1975). G.F. Pijper (1984) in his historical notes, described him as an Islamic reformer in Indonesia and al-Irsyad as a reform movement that resemble the reform movement in Egypt, like the struggle mobilized by Abduh and Rida in Jam'iyat al-Islah wal Irsyad (Association of reform and guidance). AlIrsyad espoused inevitable importance of religious reform and reconstruction and aspired to mobilized hadrami Arabs to effect change and bring social reform. This significance initiative was precisely reflected by Affandi Bisri (1976): The importance of the Irshadi movement lies in its effecting a social system in the Arab community and making a significant contribution to the birth and development of Islamic reform in Indonesia. Campaigning to promote 
justice and equality of the Muslim ummah, it rallied considerable support of the critical masses, and in the process painstakingly argued for equal rights of the Muslim, due to the fact that the hadrami Arabs were divided into two groups, the Sayyids who enjoyed elevated position and the non-Sayyids, urged Ahmad Surkati to propagate the idea of equality among Muslims. Thus, in 1913, Surkati sponsored the foundation of an Arab organization of Islamic reform called al-Irshad which has been especially influential thanks to its educational system (Affandi Bisri 1976).

Persatuan Islam (Islamic Union) or Persis, was established in 1923 in Bandung. Traditionally, it was considered by far the most puritan of Indonesia's reform movements and it develops religious attitude close to that of Saudi Salafism (Farish 2008). From its traditional perspective, and in the context of religious reform, Persatuan Islam was founded to "enlarge discussions on religious topics" (Federspiel 2009), advocating classical and traditional teaching of Islam, and historically was the most influential reformist movement. Its most prominent member was Ahmad Hassan, the leading Muslim puritanist, who joined Persatuan Islam in 1924, and whose viewpoint gave real format and individuality to the Persatuan Islam and clearly placed it in the modernist Muslim camp (Federspiel 2009). Ahmad Hassan (born 1887) was hailed from Singapore in the midst of TamilMuslim community. Early in 1920, he visited Surabaya and had discussions with traditional religious scholars on the issues of differences between Kaum Tua and Kaum Muda. Such discussion apparently struck a responsive string in Ahmad, that he subsequently developed a viewpoint that was in basic conformity with the Kaum Muda...and centered his life increasingly on religion and what he considered to be the defence of Islam (Federspiel 2009). A. Hassan himself was a regular subscriber to al-Manar and al-'Urwa al-Wuthqa, and his active involvement in Persis had brought to surface the competency of A. Hassan, who was regarded as one of the most influential islah personalities in Indonesia (Abdullah, M. 2012). 
Persatuan Islam espoused the principle of independent reasoning (ijtihad) and held that "new investigation and interpretation of religious fundamentals were necessary, rather than relying on the tradition and past interpreters of Islam" (Federspiel 2001). This principle stance echoes Abduh's scrupulous thoughts in defending reason and restoring the notion of ijtihad. Such intense concern for rationalism and speculative theology was reflected by Michale Laffan in his work of his progressive thought and idealism: Often labelled as Islamic modernism, Muhammad Abduh advocated the adoption of western technologies and systematic educational methods not in direct conflict with Islamic values. Furthermore, he outlined an approach to "return" to a pure understanding of Islam by interpreting the Qur'an and the sunna through the use of independent and rational investigation (ijtihad) above the allegedly blind reliance (taqlid) upon the opinions of the medieval jurists (Laffan 2004).

Sumatera Thawalib was a modern Islamic boarding school initiated by Haji Abdul Karim Amrullah in 1915 to advance Islamic schooling and education in Indonesia. It strived to modernize Islamic institutions and introducing modern, scientific-oriented religious schools in Indonesia. The school was established in Padang Panjang, West Sumatra as significance based and unprecedented platform to launch and drive educational reform. Abduh's seminal Tafsir al-Manar has become a compulsory text, rigorously taught in the school and became part of the required syllabus for all students at level VI and VII (Yunus M. 1960). The impressive curriculum and active programme of reform that was laid out inspired the prominent scholar Shaykh Muhammad Jamil Djambek to collaborate and realize this ideal in Sumatera Thawalib. Working closely with Haji Abdul Karim Amrullah, he helped to propagate and espoused modernist Islam in an attempt to modernize its pedagogy, brought forth progressive views into the schools, classes, subjects, and curriculum, establishing a modern system of learning and teaching. 


\section{On Rationality}

The rational interpretation of Islam and progressive religious views propounded by Muhammad Abduh in his groundwork Risalat alTauhid had attracted many liberal and rational thinkers in Indonesia, most notably was Harun Nasution (1919-1998). Nasution, the great exponent of Mu'tazilite rationalism, was firmly convinced that the revival of Mu'tazila thought was essential for the modernization of Islam (Richard C. Martin 1997). He espoused significant rational philosophy of medieval kalam and was regarded as one of the few contemporary scholars in Indonesia who aspired to revive the spirit of modernization with his rational theology of Islam (Assad Nimer 1976). He aspired to develop the discursive and critical theology of Mu'tazilite and strongly believed in the need for Muslims to free themselves from the rigid and fatalistic theologies of the Ash'ariyya and Jabariyya. Such compelling effort to restore the rational theology was substantively acclaimed in the context of Islamic modernism and his was hailed as an important voice and great proponent of reason and precursor of reform ignited by Abduh in Cairo. Abduh's rational theology profoundly influences Nasution's deeply modernist orientation and neo-Mu'tazilite views on the supremacy of reason and significant of kalam, as evidenced in his compelling work Islam Rasional: Pemikiran dan Gagasan. According to Nasution, theology developed by the Mu'tazilah and 'Abduh, is not merely an intellectual exercise or an academic enterprise, but instead has become the theological basis of the Islamic modernism (Seng Huat Tan 1961).

The Egyptian reformism had a compelling influence on his thoughts while studying at al-Azhar University in Cairo in 1940s while pursuing his degrees, and subsequently after his studies were interrupted, at the American University of Cairo after Indonesia's independence. In 1968, Nasution wrote his doctoral thesis at Mcgill University carrying the title "The place of reason in 'Abduh's theology: its impact on his theological system and views" that explores the essence of Abduh's theological premises and its rational principle. The work examined Abduh's progressive theology, and its underlying 
method of speculative and rational arguments, summarizing the essential point of his views that clearly supported the position of Mu'tazilite. This viewpoint was scrupulously examined by Nasution (1968):

Reason is an important focus-word in 'Abduh's worldview and has a great influence on his theological system and views. Because of his position of ascribing great powers to reason and limited functions to revelation, his system and views are in glaring contradiction with those of the Ash'ariya who have a distrust in the power of reason and great reliance on revelation. His system and views, on the other hand, greatly resemble those of the Mu'tazila who have been wellknown for their high appreciation of the power of reason and little reliance on revelation...contrary to the prevalent opinion, 'Abduh is neither an Ash'ari, nor a Maturidi, nor an eclectic. He is rather a Mu'tazili.

From this brief discussion, it can be pointed out that Abduh's essential ideas has deeply penetrated into the Indonesian consciousness thanks to the indefatigable effort of al-Azharite alumnus and activist who were instrumental in espousing Abduh's modern aspiration and his philosophical tradition into the region. The transmission of Abduh's modernism into Indonesia can be attributed to this mission and endeavor by Egyptian students and their alHaramayn counterpart to idealize and advocate Abduh's works and idealism.

The common thread underlying this process was essentially the rational principle and progressive ideal advocated by Abduh. This was intrinsically the motivating factors that inspired their increasing role to espoused his modernist cause. Abduh's principle has significant impact in religious reform that critically challenge the decadent and conservative ideas of old guard and seek to provide the solution to the current malaise of the ummah. This has inspired unprecedented reform in the first half of the twentieth century that resonated and espoused his rational principle and progressive understanding of Islam. 
It can be argued that al-Manar's progressive and liberal outlook was the underlying cause for this unprecedented influence evident in the its vast appeal in Indonesia. Abduh's philosophical tradition has largely become essential part of school curriculum and his works has been influential as compulsory text in the religious school. This has produced significant generation of Muslim activist that continued to carried on his tradition. In this way his rational outlook has motivated the progressive spirit of Islam and reassert its modern significance and the revival of its intellectual and scientific tradition.

\section{Conclusion}

The paper has discussed at length the influential tradition of Abduh's reformism and compelling significant of his vision for Indonesia. The reform movement had significant impact in diverse spectrum of scholarly undertaking ranging from the works of tafsir, journal, newspapers, magazines, institutions, schools and movements. The principal aims of his reform was to espouse and reconstruct the progressive Islamic worldview and accommodate it to the modern requirements of contemporary need of highly scientific and dynamic civilization. Abduh's pervasive influence on modern Islamic thought and new religious consciousness can be attributed to several factors; his dynamic aspiration for religious reform and renewal; his inclusive approach to reconstruct universal ideals; his defining method to restore the leading role of the ummah; his uncompromising struggle and aspiration to espouse the superiority of reason and definitive ijtihad (independent reasoning); his rational approach and compelling ideas of islah (reform), maslahah (common welfare), 'alamiyah (universalism), wasatiyah (principle of moderation), and maqasid al-shari'ah (higher objectives of Islamic law) and; his great commentary, al-Manar, that provides compelling answers and solutions to current malaise of the ummah. Abduh's contribution in forging modern and progressive Islamic consciousness and radical change in Indonesia cannot be underestimated; his tafsir bil-'aql or tafsir bil-ra'y (rational commentary) ignited a new scientific and socio- 
ethical tradition of tafsir. His compelling ideal spurred the rise of reputed journals, printing house and press, newspapers, movements and institutions in the continent, instigating dynamic reform in Indonesia. Abduh's legacy regarding the need for Islamic reform and renewal remains a mission worth pursuing to ensure civilizational progress and promising future for tomorrow.

\section{REFERENCES}

Abduh, M. 1999. Tafsir Juz 'Amma, terj. Muhammad Bagir, Bandung: Mizan.

Abduh, M. 1966. The Theology of Unity, trans. Ishaq Masa'ad and Kenneth Cragg. London: Allen and Unwin.

Abdullah, M., S. Arifin \& K. Ahmad. 2012. The Influence of Egyptian Reformists and its Impact on the Development of the Literature of Qur'anic Exegesis Manuscripts in the Malay Archipelago. Arts and Social Sciences Journal, vol: 52.

Adams, C. C. 1968. Islam and Modernism in Egypt: A Study of the Modern Reform Movement Inaugurated by Muhammad 'Abduh. New York: Russell \& Russell.

Affandi, B. 1976. Shaykh Ahmad al-Surkati: his Role in al-Irshad Movement in Java in the Early Twentieth Century. Master of Arts, Department of Islamic Studies, McGill University.

Afaf Lutfi al-Sayyid. 1968. Egypt and Cromer: A Study in AngloEgyptian Relationship, London: Murray.

Asad, M. 1980. The Message of the Qur'an, Gibraltar: Dar al-Andalus. Ash-Shieddiqy, M. H. 1956. Tafsier al-Quranul Madjied "An-Nur", Djuzu' 1-2, Jakarta: C.V. Bulan Bintang.

Ash-Shiddieqy, T.M. H. 1966. Tafsir al-Bayan, 2 jil, Bandung: AlMaarif.

Assad, N. B. 1976. Shaykh Muhammad Rashid Rida's Relations with Jamal al-Din al-Afghani and Muhammad 'Abduh. The Muslim World, 66 (4): 272-286.

Azra, A. 2002. Islam Nusantara: Jaringan Global dan Lokal, Bandung: Mizan. 
Azra, A. 2004. The Origins of Islamic Reformism in Southeast Asia: Networks of Malay-Indonesian and Middle Eastern 'Ulama' in the Seventeenth and Eighteenth Centuries, Honolulu: University of Hawai'i Press.

Azra, A. 2006. The Transmission of al-Manar's Reformism to the Malay-Indonesian World: The Case of al-Imam and al-Munir. In Stephane, A. D., Komatsu, H. \& Kosugi, Y. (eds.), Intellectuals in the Modern Islamic World: Transmission, Transformation and Communication, London \& New York: Routledge.

Benda, H. 1970. Southeast Asian Islam in the Twentieth Century. In P.M. Holt et al. (ed.), Vol: 2. The Cambridge History of Islam, London: Cambridge University Press.

Bluhm, W. J. 1983. A Preliminary Statement on the Dialogue Established between the Reform Magazine Al-Manar and the Malayo-Indonesian World. In Indonesia Circle, pp. 35-42.

Bluhm, W. J. 1997. Al-Manar and Ahmad Soorkattie. Links in the Chain of Transmission of Muhammad 'Abduh's Ideas to the Malay-Speaking World. In Peter G. R. \& Tony S., (eds.), Islam: Essays on Scripture, Thought and Society. Leiden: Brill.

Farish A. N., Yoginder, S. \& Martin V. B., (eds.). 20o8. The Madrasa in Asia: Political Activism and Transnational Linkages. Amsterdam: Amsterdam University Press.

Federspiel, H. M. 2001. Islam and Ideology in the Emerging Indonesia State, Leiden: Brill NV.

Federspiel, H. M. 2009. Persatuan Islam: Islamic Reform in Twentieth Century Indonesia, Singapore: Equinox Publishing.

Gibb, H.A.R. 1947. Modern Trends in Islam, Chicago: Chicago University Press.

George, M. K. 1952. Nationalism and Revolution in Indonesia, Ithaca: Cornell University Press.

Hassan, A. H., Abbas, Z. A., \& Haitami, A. R. 1954. Tafsir al-Quran alKarim: Ambilan daripada Tafsir al-Syeikh al-Tantawi alJauhari, Muhammad Abduh, al-Tabari, al-Syaukani dan lainlainnya, Pulau Pinang: Persama Press.

Hassan, A. H., Abbas, Z. A., \& Haitami, A. 196o. Tafsir al-Quranul Karim, cet. V, Medan: Yayasan Persatuan Amal Bakti Sumatera Utara. 
Hafiz, Z. 2007. From Cairo to the Straits Settlements: Modern Salafiyyah Reformist Ideas in Malay Peninsula. Intellectual Discourse, 15 (2): 125-146.

Hajid, R.H. 1954. Falsafah Pelajaran Kj. H. Ahmad Dahlan, Yogyakarta: P.B. Muhammadiyah.

Hamid, I. 1985. Peradaban Melayu dan Islam, Petaling Jaya: Fajar Bakti Publication.

Hamka. 1952. K.H.A. Dahlan. In Encyclopaedi Islam Indonesia. Orang-Orang Besar Islam di Dalam dan di Luar Indonesia, Jakarta: Sinar Pujangga.

Hamka. 1958. Pengaruh Muhammad Abduh di Indonesia (Pidato diucapkan sewaktu menerima gelar Doktor Honoris Causa di Universitas al-Azhar, Mesir pada 21 Jan 1958). Jakarta: Tintamas.

Hamka. 1967. Tafsir al-Azhar, Jakarta: P.T. Pembimbing Masa.

Hamka. 1967. Ajahku. Jakarta: Djajamurni.

Hamka. 1990. Tafsir al-Azhar, Singapura: Pustaka Nasional.

Hashim, R. (ed.). 2010. Reclaiming the Conversation: Islamic Intellectual Tradition in the Malay Archipelago, Petaling Jaya: The Other Press.

Hourani, A. 1962. Arabic Thought in the Liberal Age 1789-1939, Oxford: Oxford University Press.

Howard M. Federspiel. Popular Indonesian Literature of the Qur'an. New York: Cornell Modern Indonesia Project, 1994.

Howard M. Federspiel. Kajian al-Qur'an di Indonesia dari Mahmud Yunus hingga Quraish Shihab, terj. Drs. Tajul Arifin. Bandung: Penerbit Mizan, 1996.

Ibn 'Ashur, Muhammad al-Fadil. 1996. Al-Tafsir wa- Rijaluhu, Tunis: Dar al-Kutub al-Sharqiyya.

Ishak, M. S. 2007. Islamic Rationalism: A Critical Evaluation of Harun Nasution's Thought. Ph.d Thesis in Usuluddin and Islamic Thought, Kulliyyah of Islamic Revealed Knowledge and Human Sciences, International Islamic University Malaysia.

Jajat, B. 2004. The Fragmentation of Religious Authority: Islamic Print Media in Early 2oth Century in Indonesia. Studia Islamika, vol. 11 (1). 
Jajat, B. 2005. Aspiring for Islamic Reform: Southeast Asian Requests for Fatwas in Al-Manar. Islamic Law and Society, 12 (1): 9-26.

John O. V. 1982. Islam: Continuity and Change in the Modern World, Boulder, Co: Westview Press.

Laffan, M. 2004. An Indonesian Community in Cairo: Continuity and Change in a Cosmopolitan Islamic Milieu. Indonesia, 77: 1-26.

Milhan, Y. 1995. Hamka's Method of Interpreting the Legal Verses of the Quran: A Study of his Tafsir al-Azhar. M.A. Diss, Institute of Islamic Studies, Mcgill University.

Muhammady, I. 1975. Kiyai Haji Ahmad Dahlan His Life and Thought. M.A. Thesis, Department of Islamic Studies, McGill University, Montreal.

Nadzirah, M. 2006. Athar Madrasat al-Manar fi al-tafasir alMalayuwiyah: tafsir al-Qur'an al-hakim li-Shaykh Mustafa 'Abd al-Rahman Mahmud unmudhajan. Ph.D Thesis, Kulliyyah of Islamic Revealed Knowledge \& Heritage and Human Sciences, International Islamic University Malaysia.

Naseer, H. Aruri. 1977. Nationalism and Religion in the Arab World: Allies of Enemies. The Muslim World, 67 (4): 266-279.

Nasution, H. 1968. The Place of Reason in 'Abduh's Theology: Its Impact on his Theological System and Views. Ph.D Thesis, Institute of Islamic Studies, McGill University, Montreal.

Nasution, H. 1992. et. al. Ensiklopedi Islam Indonesia, Jakarta: Djambatan.

Natalie N. M. K. 1996. The Arab Periodicals of the Netherlands East Indies, 1914-1942. In Bijdragen tot de Toal-, Land-en Volkenkunde, Leiden, 152 (2), 236-256.

Noer., D. 1973. The Modernist Muslim Movement in Indonesia 19001942, London \& Kuala Lumpur: Oxford University Press.

Noer, D. 1982. Gerakan Moderen Islam di Indonesia 1900-1942, Jakarta: LP3ES.

Pijper, G.F. 1984. Beberapa Studi tentang Sejarah Islam di Indonesia 1900-1950, terj. Dr. Tudjimah \& Drs. Yessy Dagusdin, Jakarta: Universitas Indonesia.

Richard, C. Martin, Mark R. Woodward \& Dwi S. Atmaja. 1997. Defenders of Reason in Islam: Mu'tazilism from Medieval School to Modern Symbol. Oxford: Oneworld Publications. 
Ridā. Muhammad Rashīd. 1931. Tarikh al-Ustadh al-Imam Muhammad 'Abduh. Egypt: Matba'ah al-Manar.

Seng, H. T. 1961. The Life and Time of Syed Sheikh bin Ahmad alHadi. B.A. Thesis, University of Singapore.

Solichin, S. 196o. Kiyai Haji Ahmad Dahlan. The Indonesian Herald.

Solichin, S. 1963. K.H. Ahmad Dahlan Reformer Islam Indonesia. Jakarta: Jayamurni.

Syamsuri, A. 1997. Al-Munir dan Wacana Pembaharuan Pemikiran Islam 1911-1915. Master Thesis, IAIN Imam Bonjol, Padang.

Wan Sabri, W. Y. 1997. Hamka’s Tafsir al-Azhar: Qur'anic Exegesis as a Mirror of Social Change. Ph.D Thesis, Temple University.

Yunus M. 196o. Sejarah Pendidikan Islam di Indonesia, Djakarta: Pustaka Mahmudiah. 